\title{
IgG4-related disease of the head and neck
}

\section{Choroba IgG4 zależna w zakresie głowy i szyi}

\section{Michał Gontarz, Grażyna Wyszyńska-Pawelec, Jan Zapała}

Katedra Chirurgii Czaszkowo-Szczękowo-Twarzowej, Onkologicznej i Rekonstrukcyjnej, Instyłut Stomatologii, Uniwersytet Jagielloński Collegium Medicum, Kraków, Polska

Department of Cranio-Maxillofacial, Oncological and Reconstructive Surgery, Insitute of Dentistry, Jagiellonian University Collegium Medicum, Cracow, Poland

Head: prof. J. Zapała

\begin{abstract}
IgG4-related disease is a rare immune-mediated condition characterized by fibrosis and infiltration of IgG4-positive plasma cells in a single or as a generalised condition. Clinically, IgG4-related disease may mimic malignant and inflammatory disorders. The head and neck region is overall the second most common site, followed by the pancreas. In the head and neck this condition may involve salivary glands, the orbit, lymph nodes, the thyroid gland, the upper respiratory tract and skin. Many disorders previously regarded as single-organ diseases, such as Küttner's tumour, Mikulicz's disease and Riedel's thyroiditis are now regarded as IgG4-related diseases. This paper presents diagnostic criteria, clinicopathological features depending on the affected site as well as the treatment protocols. Due to insufficient awareness in the medical community the IgG4-related disease is often unrecognised, and in consequence leads to serious organ damage as a result of dense fibrosis, and may even cause death of the patient.
\end{abstract}

\section{KEYWORDS:}

IgG4-related disease, Küttner's tumour, Mikulicz's disease, lymph nodes, orbit

\section{Introduction}

IgG4-related disease (IgG4-RD) is a rare systemic disease of immunologic origin, which may mimic malignant neoplasm or infection. In the course of this disease a single organ can be involved and other areas may be affected after many years. ${ }^{1,2}$ IgG4-RD was firstly

\section{Streszczenie}

Choroba IgG4 zależna stanowi rzadka jednostke chorobowa o podłożu immunologicznym, charakteryzująca się zwtóknieniem oraz naciekami plazmocytów IgG4 dodatnich $w$ obrębie jednego narzadu lub w postaci uogólnionej. Klinicznie choroba IgG4- zależna może imitować nowotwór zlośliwy lub infekcje. Zmiany $w$ zakresie glowy $i$ szyi stanowia drugi obszar pod względem częstości występowania tego schorzenia po trzustce. W obrębie glowy i szyi schorzenie może dotyczyć gruczołów ślinowych, oczodotu, węzłów chtonnych, tarczycy, górnych dróg oddechowych oraz skóry. Do choroby IgG4-zależnej zaliczono jednostki chorobowe, które wcześniej byty uważane za zmiany charakterystyczne dla danego narządu, takie jak: guz Küttnera, chorobę Mikulicza oraz zapalenie tarczycy Riedla. W pracy przedstawiono kryteria diagnostyczne, objawy choroby w zależności od zajętego obszaru anatomicznego oraz leczenie. Ze względu na mała wiedzę o tym schorzeniu w środowisku medycznym, choroba IgG4-zależna często jest nierozpoznawana, co może prowadzić do poważnego uszkodzenia narzadów w nastepstwie nadmiernego ich włóknienia, a nawet do śmierci pacjenta.

\section{HASEA INDEKSOWE:}

choroba lgG4-zależna, guz Küttnera, choroba Mikulicza, węzły chłonne, oczodół

\section{Wstęp}

Choroba IgG4-zależna stanowi ogólnoustrojowe schorzenie o podłożu immunologicznym mogące imitować nowotwór złośliwy lub infekcję. Proces chorobowy może być zlokalizowany w zakresie jednego narządu, a zajęcie innych obszarów może wystąpić w okresie nawet wielu 
described by Hamano et al. in 2001, who found a correlation between the occurrence of sclerosing pancreatitis and increased serum level of IgG4. Furthermore, they observed infiltration of IgG4positive plasma cells in the pancreas as a result of this disease. ${ }^{3,4}$ In the next years, based on histopathological and serological examination, other diseases of various organs and of uncertain aetiology were classified as a IgG4-RD. In the course of IgG4-RD, besides pancreas, other sites can be involved such as bile ducts, liver, retroperitoneal space, lungs, mediastinum, kidneys, aorta, salivary glands, lacrimal glands, thyroid, lymph nodes, paranasal sinuses, pituitary gland, skin, prostate, and meninges. . $^{2,5,6}$ The infiltration of IgG4+ plasmocytes was found in such diseases as sclerosing cholangitis, retroperitoneal fibrosis, inflammatory abdominal aortic aneurysm, inflammatory pseudotumours, Küttner's tumour, Mikulicz's disease and Riedel's thyroiditis. ${ }^{1,2,7-11}$ The aetiology of IgG4-RD is unknown. Genetic, autoimmune background, and Helicobacter pylori infection can be aetiological factors for IgG4-RD. 6,12-18 However, aetiopathogenesis and pathomechanism of this disease is still uncertain.

\section{Epidemiology}

The epidemiological evaluation of IgG4-RD incidence is difficult due to insufficient awareness and a limited number of epidemiological studies. In Japan, the incidence of IgG4-RD of the pancreas is 2.2 cases per 100000 population. ${ }^{19}$ Nevertheless, the pancreas is one of many organs that may be involved in this disease, and the head and neck area is the next region, second only to pancreas. ${ }^{20}$

The IgG4-RD is more common in men in middle or senile age. ${ }^{19,21,22}$ For example, IgG4related pancreatitis occurs at the age of 67 years on average, three times more often in men than in women. ${ }^{19}$ On the other hand, IgG4-RD is observed in the head and neck region with similar frequency in men and women, aged 64 years on average. ${ }^{11}$ There is currently no confirmed family history of the genetic background of IgG4-RD. ${ }^{2}$ lat. ${ }^{1,2}$ Po raz pierwszy choroba IgG4 zależna została opisana przez Hamano i wsp. w 2001 roku, którzy stwierdzili korelację pomiędzy wystąpieniem stwardniającego zapalenia trzustki a wysokim mianem immunoglobuliny IgG4 w surowicy krwi. Ponadto zaobserwowali obecność nacieków z plazmocytów IgG4 dodatnich w obrębie trzustki w wyniku tego schorzenia. ${ }^{3,4} \mathrm{~W}$ następnych latach, na podstawie oceny histopatologicznej i serologicznej kolejne jednostki chorobowe dotyczące innych narządów zostały sklasyfikowane jako choroba IgG4-zależna. W przebiegu choroby IgG4-zależnej, oprócz trzustki, mogą być również zajęte takie narządy i przestrzenie jak: drogi żółciowe, wątroba, przestrzeń zaotrzewnowa, płuca, śródpiersie, nerki, aorta, gruczoły ślinowe, gruczoły łzowe, tarczyca, węzły chłonne, jama nosowa z zatokami przynosowymi, przysadka, skóra, prostata oraz opony mózgowo-rdzeniowe..$^{2,5,6}$ Obecność nacieków z plazmocytów IgG4 dodatnich stwierdzono w takich jednostkach chorobowych jak: stwardniające zapalenie dróg żółciowych, zwłóknienie przestrzeni zaotrzewnowej, tętniak zapalny aorty brzusznej, rzekome guzy zapalne, guz Küttnera, choroba Mikulicza oraz zapalenie tarczycy Riedla. ${ }^{1,2,7-11}$ Etiologia choroby IgG4-zależnej jest nieznana. Przyczyną rozwoju może być podłoże genetyczne, autoimmunologiczne oraz infekcja Helicobacter pylori. ${ }^{6,12-18}$ Obecnie jednak brak ostatecznego konsensusu na temat etiopatogenezy i patomechanizmu rozwoju tej choroby.

\section{Epidemiologia}

Ocena epidemiologiczna choroby IgG4zależnej jest utrudniona ze względu na niską czujność diagnostyczną oraz małą liczbę opracowań epidemiologicznych. W Japonii zachorowalność na IgG4- zależne zapalenie trzustki wynosi 2,2 przypadka na 100000 osób populacji. ${ }^{19}$ Niemniej trzustka stanowi jeden $\mathrm{z}$ wielu organów, które mogą być objęte chorobą IgG4zależną, a obszar głowy i szyi stanowi drugi rejon pod względem częstości jej występowania po trzustce. ${ }^{20}$

Choroba IgG4-zależna częściej jest obserwowana u mężczyzn w wieku średnim lub star- 


\section{Pathology}

\section{Clinical symptoms}

IgG4-RD may affect almost any organ and its symptoms are specific, depending on the affected organ. ${ }^{1,2}$ Usually the result of infiltration of IgG4+ plasma cells is an organ enlargement followed by its dysfunction. The course of the disease involves subacute and local symptoms that can mimic the neoplasm of the affected organ. ${ }^{1,2}$ The general sings sometimes observed are weight loss of $5-10 \mathrm{~kg}$ in a period of several months and chronic fatigue if several organs are involved. ${ }^{2}$ Due to uncharacteristic general symptoms, which sometimes are absent, the IgG4-RD is mostly detected incidentally during serological, radiological or histological examinations. ${ }^{1,23}$

\section{Histopathology}

In the diagnosis of IgG4-RD the histopathological examination is the most important one. Histologically, there is a characteristic triad of symptoms such as massive infiltration of polyclonal lymphocytes and plasma cells with a storiform fibrosis and obliterative phlebitis of the medium caliber veins. ${ }^{2,5,6}$ Also, slight or moderate infiltration of eosinophils is observed. The presence of neutrophilic infiltration is extremely rare. ${ }^{2,6}$ In the case of the salivary gland involvement infiltration of polyclonal lymphocytes and plasma cells is located in the vicinity of tubular parts of the gland. ${ }^{24}$

\section{Immunohistochemistry}

Typical histopathological features of IgG4-RD also require immunohistochemical confirmation of the presence of IgG4+ plasma cells infiltration and their semiquantitative assessment. ${ }^{2,5,6}$ IgG4 + plasma cells usually form diffuse, rarely circumscribed infiltration. In addition, the total number of IgG4+ plasmocytes must be assessed in relation to the affected organ. In the case of salivary glands involvement IgG4-RD is confirmed by the presence of $100 \mathrm{IgG} 4+$ plasma cells in the high power field - HPF. In the case of pancreas involvement, the cutoff value is 50 IgG4+ plasmocytes per HPF. Nevertheless, the cutoff number of IgG4 + plasma cells per HPF for czym. ${ }^{19,21,22}$ Przykładowo IgG4-zależne zapalenie trzustki występuje średnio w wieku 67 lat, trzykrotnie częściej u mężczyzn niż u kobiet. ${ }^{19}$ Z kolei w obszarze głowy i szyi choroba ta obserwowana jest $\mathrm{z}$ podobną częstością u mężczyzn i kobiet, średnio w wieku 64 lat. ${ }^{11}$ Obecnie nie potwierdzono rodzinnego występowania choroby IgG4-zależnej na podłożu genetycznym. ${ }^{2}$

\section{Patologia \\ Objawy kliniczne}

Choroba IgG4-zależna może dotyczyć niemal każdego narządu, a jej objawy są specyficzne $\mathrm{w}$ zależności od zajęcia danego organu. ${ }^{1,2}$ Najczęściej w wyniku nacieków z plazmocytów IgG4 dodatnich dochodzi do masywnego zajęcia danego narządu z następową jego dysfunkcją. Przebieg schorzenia jest podostry, a objawy miejscowe mogą imitować rozrost nowotworowy. ${ }^{1,2}$ W stanie ogólnym może dojść do spadku masy ciała o 5-10 kg w okresie kilku miesięcy oraz uczucia przewlekłego zmęczenia w przypadku zajęcia kilku narządów przez chorobę. ${ }^{2}$ Ze względu na niecharakterystyczne objawy ogólne, które niekiedy mogą nie występować, choroba IgG4-zależna jest najczęściej wykrywana przypadkowo, podczas diagnostyki laboratoryjnej, radiologicznej lub histopatologicznej. ${ }^{1,23}$

\section{Obraz histopatologiczny}

W rozpoznaniu choroby IgG4-zależnej badanie histopatologiczne odgrywa kluczową rolę. W obrazie histologicznym występuje charakterystyczna triada objawów w postaci masywnych nacieków z poliklonalnych limfocytów i plazmocytów wraz z promienistym zwłóknieniem tkanek (storiform fibrosis) oraz obliterującym zapaleniem żył średniego kalibru (obliterative phlebitis). ${ }^{2,5,6} \mathrm{~W}$ preparatach również obserwowane są niewielkie lub średnio nasilone nacieki z eozynofilów. Natomiast obecność nacieków neutrofilowych jest niezmiernie rzadka. ${ }^{2,6} \mathrm{~W}$ przypadku zajęcia przez proces chorobowy narządów gruczołowych nacieki limfocytarno-plazmocytarne zlokalizowane są w okolicy struktur przewodowych gruczołu. ${ }^{24}$ 
diagnosis of IgG4-RD is still a controversial issue. Furthermore, the ratio of IgG4+ placmocytes to $\mathrm{IgG}+$ plasmocytes must be at least $40 \%$, typically approximately $70 \% .^{2}$ In advanced stages of IgG$\mathrm{RD}$ proper diagnosis is more difficult because of the lower percentage of plasmocytes infiltration and the presence of massive fibrosis. ${ }^{2,6}$

\section{Diagnosis}

The gold standard in the diagnosis of IgG4$\mathrm{RD}$ is a characteristic triad of histopathological symptoms related to the clinical symptoms. ${ }^{5}$ Diagnostic imaging is supplementary in the diagnosis of this disease, and images in CT and MR are uncharacteristic. ${ }^{2,6}$ On the other hand, PET/CT is useful in assessing the extent of the disease in a particular organ and monitoring the activity of the disease after treatment. ${ }^{25}$ In the differential diagnosis, malignancies, including lymphoma, also Sjögren's syndrome, sarcoidosis, and Castleman's disease must be initially excluded. ${ }^{2,5}$ Most patients suffering from IgG4-RD have increased serum level of $\operatorname{IgG} 4$ ( $>135 \mathrm{mg} / \mathrm{dL}) .5,11$ However, the mere increase of the serum level of IgG4 or only the presence of IgG4+ plasma cells infiltration in a histological specimen are not always indicative of IgG4-RD. ${ }^{5}$

Definitive diagnosis of IgG4-RD is confirmed when the following diagnostic criteria are present:

- enlargement of the organ, the tumour within an organ or organ dysfunction,

- elevated serum level of immunoglobulin IgG4 (>135mg/dL),

- immunohistochemical presence of $>10$ IgG4+ plasma cells/HPF and the ratio of IgG4+/ IgG+ plasmocytes above $40 \%$.

Possible diagnosis of IgG4-RD is made when the patient meets the 1st and 2nd criteria, without 3 rd criterion or lack of histopathological examination. Probable diagnosis of IgG4-RD is made when the patient fulfills the 1st and 3rd criteria, without increased serum level of IgG4. ${ }^{1,26}$

\section{IgG4-RD in the head and neck region Salivary glands}

Major and minor salivary glands can be affected by IgG4-RD. One example is chronic sclerosing

\section{Immunohistochemia}

Typowy obraz histopatologiczny choroby IgG4-zależnej dodatkowo wymaga potwierdzenia immunohistochemicznego obecności nacieków z plazmocytów IgG4 dodatnich i ich oceny półilościowej. 2,5,6 Plazmocyty IgG4+ najczęściej tworzą rozlane nacieki, rzadko ogniskowe. Ponadto liczba całkowita plazmocytów IgG4+ musi być oceniana w stosunku do badanego narządu. W przypadku gruczołów ślinowych wartością graniczną rozpoznania choroby IgG4zależnej jest obecność 100 plazmocytów IgG4 dodatnich w polu widzenia (high power field HPF). Natomiast w przypadku trzustki wartość graniczna wynosi 50 komórek w polu widzenia (HPF). Niemniej wartości graniczne liczby plazmocytów IgG4+/HPF dla rozpoznania choroby IgG4-zależnej są nadal kwestią sporną. Ponadto stosunek plazmocytów IgG4 dodatnich do plazmocytów IgG dodatnich musi wynosić przynajmniej 40\%, najczęściej wynosi około $70 \%{ }^{2}$ Zaawansowane stadium choroby IgG4-zależnej jest trudniejsze w rozpoznaniu ze względu na mniejszy odsetek nacieków plazmocytarnych z obecnością masywnego włóknienia. ${ }^{2,6}$

\section{Diagnostyka}

Złoty standard w rozpoznaniu choroby IgG4zależnej stanowi charakterystyczna triada objawów w obrazie histopatologicznym skorelowana z obrazem klinicznym. ${ }^{5}$ Diagnostyka obrazowa stanowi uzupełnienie $\mathrm{w}$ diagnostyce schorzenia, niemniej obrazy w badaniu TK oraz MR są niecharakterystyczne. ${ }^{2,6} \mathrm{Z}$ kolei badanie PET/TK jest pomocne $\mathrm{w}$ ocenie rozległości procesu chorobowego $\mathrm{w}$ danym narządzie oraz monitorowaniu aktywności schorzenia po zastosowanym leczeniu. ${ }^{25} \mathrm{~W}$ diagnostyce różnicowej należy wykluczyć przede wszystkim nowotwór złośliwy, w tym chłoniaka, a także zespół Sjögrena, sarkoidozę oraz chorobę Castelmana. ${ }^{2,5}$ Większość pacjentów cierpiących na chorobę IgG4-zależną ma podwyższony poziom miana immunoglobuliny IgG4 w surowicy krwi (>135mg/dL). ${ }^{5,11}$ Należy jednak pamiętać, iż stwierdzenie jedynie podwyższonego miana IgG4 w surowicy krwi lub obecność nacieków z komórek plazmatycznych IgG4 dodat- 
sialadenitis, which was firstly described in 1896 by Küttner. ${ }^{27}$ Firm enlargement of the salivary gland is characteristic of chronic sclerosing sialadenitis, which can suggest the presence of malignant neoplasm and consequently, another name for this condition is Küttner's tumour. In addition, Sjögren's syndrome and MALT lymphoma should also be considered in the differential diagnosis. ${ }^{28}$ Küttner's tumour is commonly observed in one submandibular gland; however, it may sometimes appear bilaterally. 1,20 Chronic sclerosing sialadenitis typically occurs in middle-aged and senile patients, slightly more often in men. ${ }^{28}$ According to some authors, sialolithiasis is the main aetiological factor for Küttner's tumour, and is observed in $29-83 \%$ of patients. ${ }^{29,30}$ On the other hand, some studies emphasize the immune background of Küttner's tumour. ${ }^{31,32}$ Furokawa et al., ${ }^{8}$ found infiltration of IgG4 + plasma cells characteristic of IgG4$\mathrm{RD}$ only in cases of Küttner's tumour developing de novo, without silaloliths. Therefore, it seems reasonable to categorise Küttner's tumour as an IgG4-RD, in contrast to chronic sialadenitis of the submandibular gland with sialolith background.

Histological foundings similar to Küttner's tumour are observed in Mikulicz's disease (MD). ${ }^{33}$ In 1888, Jan Mikulicz-Radecki ${ }^{34}$ described the case of bilateral, painless, symmetric swelling of the lacrimal glands and submandibular salivary glands. The term MD was introduced into the medical terminology in 1927 by Schaffer and Jacobsen. ${ }^{35}$ For nearly half a century, MD was considered to be a subtype of Sjögren's syndrome (SS). However, differences between MD and SS are shown in Table 1.9,10

Moreover, Aga et al., described the case of coexistence of Warthin's tumour and IgG4-RD as well as elevated serum level of IgG4 and the presence of infiltration of IgG4 + plasma cells in patients with Warthin's tumour. ${ }^{36,37}$ According to their theory, the aetiology of inflammatory component of the Warthin's tumour has an immune background, which may explain frequent bilateral or multifocal occurrence of Warthin's tumour in the parotid gland. ${ }^{36,37}$ nich w preparacie histopatologicznym nie zawsze świadczy o chorobie IgG4-zależnej. ${ }^{5}$

Definitywne (definitive diagnosis) rozpoznanie choroby IgG4-zależnej można stwierdzić u pacjenta, u którego potwierdzono występowanie następujących kryteriów diagnostycznych:

- powiększenie danego narządu, guz w zakresie narządu lub jego dysfunkcję,

- podwyższony poziom miana immunoglobuliny IgG4 w surowicy krwi ( $>135 \mathrm{mg} / \mathrm{dL})$,

- w badaniu histopatologicznym obecność $>10$ plazmocytów IgG4+/HPF oraz stosunek IgG4+/IgG+ powyżej $40 \%$.

Możliwe (possible diagnosis) rozpoznanie choroby IgG4-zależnej występuje w przypadku spełnienia 1 i 2 kryterium, bez spełnienia 3 kryterium lub braku badania histopatologicznego. Z kolei prawdopodobne (probable diagnosis) rozpoznanie choroby IgG4- zależnej występuje u chorych spełniających 1 i 3 kryterium, jednakże z prawidłowym poziomem miana IgG4 w surowicy krwi. ${ }^{1,26}$

\section{Narządy objęte chorobą w zakresie glowy i szyi Gruczoly ślinowe}

Duże i małe gruczoły ślinowe mogą być objęte opisywanym procesem chorobowym. Przykładem choroby IgG4 zależnej jest przewlekłe, stwardniające zapalenie gruczołu ślinowego (chronic sclerosing sialadenitis) po raz pierwszy opisane w 1896 roku przez Küttnera. ${ }^{27}$ Obraz kliniczny może imitować nowotwór złośliwy gruczołu ślinowego, dlatego też przyjęto nazwę guza Küttnera. Ponadto w diagnostyce różnicowej należy uwzględnić zespół Sjögrena oraz chłoniaka typu MALT. ${ }^{28}$ Guz Küttnera najczęściej występuje w zakresie ślinianki podżuchwowej jednostronnie, niemniej może również dotyczyć obu ślinianek podżuchwowych. ${ }^{1,20}$ Przewlekłe stwardniające zapalenie gruczołu ślinowego typowo występuje u pacjentów w średnim i starczym wieku, nieco częściej u mężczyzn. ${ }^{28}$ Według niektórych autorów kamica ślinowa stanowi główny czynnik etiologiczny guza Küttnera i jest obserwowana u 29$83 \%$ pacjentów. ${ }^{29,30} \mathrm{Z}$ kolei część badań podkreśla wpływ nieprawidłowej aktywności immunologicznej organizmu na rozwój guza Küttnera. ${ }^{31,32}$ 
Table 1. Differences between Mikulicz's disease and Sjögren's syndrome

\begin{tabular}{lll} 
& Mikulicz's disease & Sï̈gren's syndrome \\
Age & $6-7$ decade & $5-6$ decade \\
\hline Sex ratio (F:M) & $3: 1$ & $20: 1$ \\
\hline Gland swelling & Persistent & Recurrent \\
\hline Dysfunction of salivary secretion & None, slight & Mild, severe \\
\hline Keratoconjunctivitis sicca & None, slight & Mild, severe \\
\hline Response to steroid & Very good & No change, or sometimes good \\
\hline Serum lgG & Normal to very high & Normal to high \\
\hline Serum lgG4 & Very high & Normal \\
\hline Antinuclear antibody & Usually negative & Usually positive \\
\hline Ratio for serum lgG4/total lgG & Severely high (30\%) & Normal (4\%) \\
\hline Anti-SS-A/SS-B antibodies & Negative & Positive (70\%/30\%) \\
\hline Histopathological findings & Dense infiltration of lgG4-positive plasmocytes & No infiltration of lgG4-positive plasmocytes \\
\hline Sialography & "Apple tree in blossom" & Cavitary sialectasia \\
\hline
\end{tabular}

\section{Orbit}

Lacrimal glands and periorbital tissues are often affected in IgG4-RD, and ophthalmologic symptoms may be the first manifestation of this disorder. Clinically, there is a painless swelling of the eyelids, sometimes with diplopia and uni- or bilateral exophthalmos. ${ }^{1,2,20}$ Exophthalmos may be caused by enlargement of the lacrimal gland or the presence of the pseudotumour in the orbital muscle and periorbital tissues. ${ }^{2}$ In the course of IgG4-RD, significant decrease of visual acuity usually does not occur. ${ }^{1,20}$ Rare ophthalmic symptoms may also include scleritis, obliteration of nasolacrimal duct and the compression of the peripheral nerves in the orbit, mainly the infraorbital nerve. ${ }^{38-41}$ In the differential diagnosis, one should take into account the lacrimal gland or orbital tumours, lymphomas and thyroid orbitopathy.

\section{Lymph nodes}

Lymphadenopathy is often found in IgG4$\mathrm{RD}$ as a generalised condition or localized in the vicinity of the affected organ. ${ }^{42}$ Most often
Wyjaśnieniem etiopatogenezy może być badanie Furokawy i wsp. ${ }^{8}$, którzy jedynie w przypadkach guza Küttnera rozwijających się de novo, bez kamicy ślinowej, stwierdzili w obrazie histologicznym obecność nacieków z plazmocytów IgG4+ charakterystycznych dla choroby IgG4-zależnej. Dlatego też wydaje się uzasadnione przyporządkowanie guza Küttnera do choroby IgG4-zależnej w przeciwieństwie do przewlekłego zapalenia ślinianki podżuchwowej rozwijającego się na podłożu kamicy ślinowej.

Podobny obraz histologiczny do guza Küttnera obserwowany jest $\mathrm{w}$ chorobie Mikulicza. ${ }^{33}$ W 1888 roku Jan Mikulicz-Radecki ${ }^{34}$ opisał przypadek obustronnego, bezbolesnego, symetrycznego obrzęku gruczołów łzowych, ślinianek przyusznych i podżuchwowych, a pojęcie choroby Mikulicza zostało wprowadzone do nazewnictwa medycznego w 1927 roku przez Schaffera i Jacobsena ${ }^{35}$. Przez blisko pół wieku chorobę Mikulicza uznawano za podtyp zespołu Sjögrena. Różnice w chorobie Mikulicza oraz zespole Sjögrena przedstawiono w tabeli $1 .^{9,10}$ 
enlarged lymph nodes are painless, with a diameter of 1-3 cm, and they are detected by imaging in patients with confirmed IgG4-RD. ${ }^{1,2}$ Sometimes lymphadenopathy is the first symptom of IgG4$\mathrm{RD}$; however, proper diagnosis based on lymph node biopsy is difficult due to a lower degree of fibrosis in lymph nodes than in other organs affected by this disease. ${ }^{2}$ In the case of generalized lymphadenopathy in the differential diagnosis we should consider lymphoma, sarcoidosis, multifocal Castleman disease and cancer metastases. ${ }^{1,43}$

\section{Thyroid gland}

Nowadays, Riedel's thyroiditis and some cases previously classified as Hashimoto's disease have been linked to IgG4-related thyroiditis. 2,7,20,44 This disease is characterised by the presence of lymphoplasmatic infiltration, IgG4+ plasma cell infiltration, fibrosis, as well as increased serum level of IgG4, often accompanied by the presence of antithyroglobulin antibodies. ${ }^{44}$ Patients with this type of disorder are characterised by subclinical hypothyroidism, rapid progression and diffuse hypoechogenic picture of the thyroid in ultrasound examination. ${ }^{45}$ The disease is more common in women, in the fourth and fifth decade of life. ${ }^{20}$

\section{Other sites in the head and neck region}

IgG4-RD may be observed in the upper respiratory tract, especially in the nose and paranasal sinuses, but also in the oral cavity, pharynx, larynx and Waldeyer ring. In the course of this disease, diffuse inflammatory and proliferative changes are observed, which lead to obliteration of the upper respiratory tract. ${ }^{1,2,20}$ In addition, some reports describe bone destruction of the maxillary sinus, the middle ear and other facial bones. ${ }^{46-50}$

IgG4-RD of the skin is very rare. In $80 \%$ of cases it is complicated by the involvement of other organs by the disease. The most common changes are localised in the head and neck region in the form of erythematous, itchy lumps or nodules under the skin around the cheek and retroauricular region. ${ }^{51}$ Some reports describe the occurrence of lesions on the trunk and extremities. ${ }^{2,51}$

IgG4-RD of the central nervous system occurs very rarely, and the most common site is the
Aga i wsp. opisali przypadek współwystępowania guza Warthina i choroby IgG4-zależnej, jak również podwyższony poziom miana $\operatorname{IgG} 4 \mathrm{w}$ surowicy krwi i obecność nacieków z plazmocytów IgG4+ w grupie chorych z guzem Warthina. ${ }^{36,37}$ Zgodnie $\mathrm{z}$ ich teorią $\mathrm{w}$ etiopatogenezie komponenty zapalnej w obrazie mikroskopowym guza Warthina bierze udział reakcja immunologiczna, co może wyjaśniać często jego obustronne lub wieloogniskowe występowanie w śliniance przyusznej. ${ }^{36,37}$

\section{Oczodót}

Gruczoły łzowe oraz tkanki okołogałkowe są często zajęte w chorobie IgG4- zależnej, a objawy okulistyczne mogą stanowić pierwszą manifestację tego schorzenia. W obrazie klinicznym występuje niebolesny obrzęk powiek, niekiedy z towarzyszącą diplopią oraz wytrzeszczem jedno lub obustronnym. ${ }^{1,2,20}$ Wytrzeszcz gałki ocznej może wynikać z powiększenia gruczołów łzowych lub z powodu guza rzekomego w zakresie mięśni gałkoruchowych i tkanek oczodołu. ${ }^{2} \mathrm{~W}$ przebiegu choroby IgG4-zależnej najczęściej nie dochodzi do znaczącego osłabienia ostrości wzroku. ${ }^{1,20}$ Ponadto do rzadszych objawów okulistycznych zalicza się zapalenie twardówki, obliterację przewodu nosowo-łzowego oraz kompresję nerwów obwodowych w obrębie oczodołu, głównie nerwu podoczodołowego. ${ }^{38-41} \mathrm{~W}$ diagnostyce różnicowej należy uwzględnić nowotwór gruczołu łzowego lub oczodołu, chłoniaka oczodołu oraz orbitopatię tarczycową.

\section{Wezaty chtonne}

Limfadenopatia często występuje w chorobie IgG4-zależnej w postaci uogólnionej lub zlokalizowanej w pobliżu zajętego narządu. ${ }^{42}$ Najczęściej powiększone węzły chłonne są niebolesne, wielkości 1-3 cm i są wykrywane w badaniach obrazowych u pacjentów $\mathrm{z}$ potwierdzoną chorobą IgG4-zależną. ${ }^{1,2}$ Niekiedy limfadenopatia stanowi pierwszy objaw choroby IgG4-zależnej, lecz prawidłowe rozpoznanie jest utrudnione na podstawie biopsji węzła chłonnego ze względu na obserwowany mniejszy stopień zwłóknienia w tkankach węzła chłonnego niż innych narządach objętych 
pituitary gland. IgG4-RD of the pituitary gland can lead to hypopituitarism and diabetes insipidus. ${ }^{1,2}$

\section{Treatment}

Glucocorticoids play the most important role in the treatment of IgG4-RD, which are the standard treatment in most patients. However, no randomised studies have been done to establish the therapeutic guidelines. Most of the studies are based on a retrospective analysis of patients treated with prednisolone. ${ }^{2,6,52}$ In the course of glucocorticoids treatment, a reduction of serum level of IgG4 and resolution of clinical and radiological symptoms are observed. In most cases, the clinical response to treatment is quick but it depends on the advancement of the disease and degree of organ fibrosis. . $^{1,20}$ The therapeutic effectiveness is assessed by serum level of IgG4 (after two weeks of treatment) and radiological evaluation in $\mathrm{PET} / \mathrm{CT}^{2,25}$ Quick response to glucocorticoids treatment can also be an additional diagnostic criterion of IgG4-RD in cases when histopathological examination cannot be performed. Moreover, improvement of saliva secretion by the salivary glands after treatment with glucocorticoids may indicate IgG4-RD instead of Sjogren's syndrome. ${ }^{2}$

Recurrence after treatment or poor response to glucocorticoids can also be treated by immunosuppressive therapy with rituximab, azathioprine, mycophenolate mofetil, and methotrexate. ${ }^{1,2,6,53}$

\section{Conclusions}

IgG4-RD is a relatively new multi-organ immune-mediated condition, which often remains unrecognised, or is diagnosed at an advanced stage due to insufficient awareness in the medical community. IgG4-RD combines many pathologies of uncertain aetiology into one syndrome. A new approach to the diagnosis and treatment of this disease sometimes could spare the patient a surgical treatment. Early diagnosis and treatment of IgG4RD help to avoid serious damage of organs in the course of their massive fibrosis. Evaluation of IgG4 serum level would be a useful tool in the screening of this disorder. Unfortunately, this procesem chorobowym. ${ }^{2} \mathrm{~W}$ przypadku uogólnionej limfadenopatii w diagnostyce różnicowej należy uwzględnić chłoniaka, sarkoidozę, wieloogniskową chorobę Castelmana oraz rozsiew nowotworu złośliwego. ${ }^{1,43}$

\section{Tarczyca}

Obecnie zapalenie tarczycy Riedla oraz część przypadków zaliczanych wcześniej do choroby Hashimoto klasyfikowane jest jako IgG4zależne zapalnie tarczycy (IgG4-related thyroiditis). ${ }^{2,7,20,44}$ Schorzenie to cechuje się obecnością nacieków limfocytarno-plazmocytarnych, nacieków z plazmocytów IgG4+, włóknieniem oraz podwyższonym mianem IgG4 w surowicy, często z towarzyszącą obecnością przeciwciał antytyreoglobulinowych. ${ }^{44}$ Chorych z tego typu schorzeniem wyróżnia subkliniczna niedoczynność tarczycy, szybka progresja oraz rozlany, hypoechogeniczy obraz tarczycy w badaniu ultrasonograficznym. ${ }^{45}$ Choroba dotyczy częściej kobiet w IV i V dekadzie życia. ${ }^{20}$

\section{Pozostate umiejscowienia $w$ rejonie glowy i szyi}

Choroba IgG4-zależna może występować w zakresie górnych dróg oddechowych, głównie w obrębie nosa i zatok przynosowych, lecz także w jamie ustnej, gardle, części krtaniowej gardła, pierścieniu Waldeyera oraz krtani. W przebiegu schorzenia powstają rozlane zmiany zapalno-rozrostowe prowadzące do obliteracji górnych dróg oddechowych. 1,2,20 Ponadto opisywano zmiany powodujące destrukcję tkanki kostnej w obrębie zatoki szczękowej, ucha środkowego oraz kości twarzy. ${ }^{46-50}$

W zakresie skóry choroba IgG4-zależna występuje rzadko. W $80 \%$ przypadków jest powikłana zajęciem innych narządów przez proces chorobowy. Najczęściej zmiany lokalizują się w regionie głowy i szyi w postaci rumieniowatych, swędzących grudek lub podskórnych guzków w okolicy zausznej oraz policzkowej. ${ }^{51}$ Ponadto opisywano występowanie zmian skórnych w obrębie tułowia oraz kończyn. 2,51

Choroba IgG4-zależna centralnego systemu nerwowego występuje bardzo rzadko, a najczęst- 
examination is hardly available and expensive. IgG4-RD should be included into the differential diagnosis of head and neck disorders, especially after neoplasms are excluded. Further studies on the aetiopathogenesis and pathomechanism of IgG4-RD are due to provide new insight into the immune system processes in humans. szą opisywaną lokalizacją jest przysadka mózgowa. W przebiegu schorzenia może dojść do niedoczynności przysadki mózgowej oraz moczówki prostej. ${ }^{1,2}$

\section{Leczenie}

W terapii choroby IgG4-zależnej kluczową rolę odgrywają glikokortykosterydy (GKS), które stanowią standard w leczeniu u większości pacjentów. Jednakże, jak do tej pory nie przeprowadzono randomizowanych badań, które pozwoliłyby na ustalenie wytycznych terapeutycznych. Większość badań opiera się na retrospektywnej analizie chorych leczonych prednizolonem. ${ }^{2,6,52}$ W przebiegu leczenia GKS dochodzi do zmniejszenia miana IgG4 w surowicy krwi oraz ustąpienia objawów klinicznych i radiologicznych. Najczęściej odpowiedź kliniczna na leczenie GKS jest szybka i jest uzależniona od czasu trwania choroby oraz stopnia zwłóknienia danego narządu. ${ }^{1,2,20} \mathrm{~W}$ ocenie skuteczności leczenia zastosowanie ma estymacja miana IgG4 w surowicy krwi (po dwóch tygodniach leczenia GKS) oraz ocena radiologiczna w PET/TK. ${ }^{2,25}$ Szybka odpowiedź na leczenie GKS także może stanowić dodatkowe kryterium diagnostyczne choroby IgG4-zależnej w przypadkach braku możliwości wykonania badania histopatologicznego. Ponadto u chorych z zajęciem gruczołów ślinowych poprawa sekrecji śliny po leczeniu GKS pozwala różnicować chorobę IgG4-zależną od zespołu Sjögrena. ${ }^{2}$

$\mathrm{U}$ chorych z nawrotem choroby po zastosowanym leczeniu lub słabą odpowiedzią na leczenie GKS stosowane jest również leczenie immunosupresyjne z użyciem rytuksymabu, azatiopryny, mykofenolanu mofetylu oraz metotreksatu. 1,2,6,53

\section{Podsumowanie}

Choroba IgG4-zależna stanowi stosunkowo nową jednostkę chorobową o podłożu immunologicznym, która ze względu na małą wiedzę na temat tego schorzenia niską czujność w środowisku medycznym często pozostaje nierozpoznana lub jest rozpoznawana $\mathrm{w}$ zaawansowanym stadium. Schorzenie to łączy ze sobą różne jednostki chorobowe o niejasnej etiologii w jeden zespół. Nowe podejście do diagnostyki oraz leczenia tego scho- 
rzenia może zaoszczędzić pacjentowi okaleczającego zabiegu chirurgicznego. Wczesne rozpoznanie i leczenie choroby IgG4 zależnej pozwala na uniknięcie poważnego uszkodzenia narządów w przebiegu nadmiernego ich włóknienia. W diagnostyce przesiewowej przydatna byłaby ocena miana IgG4 w surowicy krwi pacjenta. Badanie to niestety jest mało dostępne oraz kosztowne. Należy również pamiętać o uwzględnieniu choroby IgG4 zależnej w diagnostyce różnicowej schorzeń narządów głowy i szyi, przede wszystkim wykluczając nowotwór złośliwy u chorego. W przyszłości dalsze badania dotyczące etiopatogenezy oraz patomechanizmu choroby IgG4 zależnej z pewnością dadzą nowe spojrzenie na procesy zachodzące w układzie immunologicznym u człowieka.

\section{References}

1. Guma M, Firestein GS: IgG4-related diseases. Best Pract Res Clin Rheumatol 2012; 26: 425-438.

2. Kamisawa T, Zen Y, Pillai S, Stone JH: IgG4related disease. Lancet 2015; 385: 1460-1471.

3. Hamano H, Kawa S, Horiuchi A, Unno H, Furuya $N$, Akamatsu T, et al.: High serum IgG4 concentrations in patients with sclerosing pancreatitis. N Engl J Med 2001; 344: 732-738.

4. Hamano H, Kawa S, Ochi Y, Unno H, Shiba N, Wajiki $M$, et al.: Hydronephrosis associated with retroperitoneal fibrosis and sclerosing pancreatitis. Lancet 2002; 359: 1403-1404.

5. Deshpande V, Zen Y, Chan JK, Yi EE, Sato Y, Yoshino T, et al.: Consensus statement on the pathology of IgG4-related disease. Mod Pathol 2012; 25: 1181-1192.

6. Stone JH, Zen Y, Deshpande V: IgG4-related disease. N Engl J Med 2012; 366: 539-551.

7. Dahlgren $M$, Khosroshahi A, Nielsen GP, Deshpande V, Stone JH: Riedel's thyroiditis and multifocal fibrosclerosis are part of the IgG4related systemic disease spectrum. Arthritis Care Res (Hoboken) 2010; 62: 1312-1318.

8. Furukawa S, Moriyama M, Kawano S, Tanaka A, Maehara T, Hayashida JN, et al.: Clinical relevance of Küttner tumour and IgG4-related dacryoadenitis and sialoadenitis. Oral Dis 2015; 21: 257-262.
9. Himi T, Takano K, Yamamoto M, Naishiro $Y$, Takahashi H: A novel concept of Mikulicz's disease as IgG4-related disease. Auris Nasus Larynx 2012; 39: 9-17.

10. Yamamoto M, Takahashi H, Ohara M, Suzuki C, Naishiro Y, Yamamoto H, et al.: A new conceptualization for Mikulicz's disease as an IgG4-related plasmacytic disease. Mod Rheumatol 2006; 16: 335-340.

11. Zen Y, Nakanuma Y: IgG4-related disease: a cross-sectional study of 114 cases. Am J Surg Pathol 2010; 34: 1812-1819.

12. Aparisi L, Farre A, Gomez-Cambronero L, Martinez $J$, De Las Heras $G$, Corts $J$, et al.: Antibodies to carbonic anhydrase and $\mathrm{IgG} 4$ levels in idiopathic chronic pancreatitis: relevance for diagnosis of autoimmune pancreatitis. Gut 2005; 54: 703-709.

13. Asada M, Nishio A, Uchida K, Kido M, Ueno S, $U z a N$, et al.: Identification of a novel autoantibody against pancreatic secretory trypsin inhibitor in patients with autoimmune pancreatitis. Pancreas 2006; 33: 20-26.

14. Chang MC, Chang YT, Tien YW, Liang PC, Jan IS, Wei $S C$, et al.: T-cell regulatory gene CTLA-4 polymorphism/haplotype association with autoimmune pancreatitis. Clin Chem 2007; 53: 1700-1705.

15. Guarneri F, Guarneri C, Benvenga S: Helicobacter 
pylori and autoimmune pancreatitis: role of carbonic anhydrase via molecular mimicry? J. Cell. Mol. Med. 2005; 9: 741-744.

16. Löhr JM, Faissner R, Koczan D, Bewerunge P, Bassi $C$, Brors B, et al.: Autoantibodies against the exocrine pancreas in autoimmune pancreatitis: gene and protein expression profiling and immunoassays identify pancreatic enzymes as a major target of the inflammatory process. Am J Gastroenterol 2010; 105: 2060-2071.

17. Umemura T, Ota M, Hamano H, Katsuyama Y, Muraki T, Arakura N, et al.: Association of autoimmune pancreatitis with cytotoxic T-lymphocyte antigen 4 gene polymorphisms in Japanese patients. Am J Gastroenterol 2008; 103: 588-594.

18. Umemura T, Ota M, Hamano H, Katsuyama Y, Kiyosawa K, Kawa $S$ : Genetic association of Fc receptor-like 3 polymorphisms with autoimmune pancreatitis in Japanese patients. Gut 2006; 55: 1367-1368.

19. Kanno A, Nishimori I, Masamune A, Kikuta K, Hirota $M$, Kuriyama $S$, et al.: Research Committee on Intractable Diseases of Pancreas. Nationwide epidemiological survey of autoimmune pancreatitis in Japan. Pancreas 2012; 41: 835-839.

20. Bhatti RM, Stelow EB: IgG4-related disease of the head and neck. Adv Anat Pathol 2013; 20: 10-16.

21. Mahajan VS, Mattoo H, Deshpande V, Pillai SS, Stone JH: IgG4-related disease. Annu Rev Pathol 2014; 9: 315-347.

22. Umehara H, Okazaki K, Masaki Y, Kawano M, Yamamoto M, Saeki T, et al.: Research Program for Intractable Disease by Ministry of Health, Labor and Welfare (MHLW) Japan G4 team.: A novel clinical entity, IgG4-related disease (IgG4RD): general concept and details. Mod Rheumatol 2012; 22: $1-14$.

23. Fujita A, Sakai O, Chapman MN, Sugimoto $H$ : IgG4-related disease of the head and neck: CT and MR imaging manifestations. Radiographics 2012; 32: 1945-1958.

24. Deshpande V, Gupta R, Sainani N, Sahani DV, Virk $R$, Ferrone $C$, et al.: Subclassification of autoimmune pancreatitis: a histologic classification with clinical significance. Am J Surg Pathol 2011; 35: 26-35.

25.Ebbo M, Grados A, Guedj E, Gobert D, Colavolpe $C$, Zaidan $M$, et al.: Usefulness of 2-[18F]-fluoro2-deoxy-D-glucose-positron emission tomography/ computed tomography for staging and evaluation of treatment response in IgG4-related disease: a retrospective multicenter study. Arthritis Care Res
(Hoboken) 2014; 66: 86-96.

26. Umehara H, Okazaki K, Masaki Y, Kawano M, Yamamoto $M$, Saeki T, et al.: Comprehensive diagnostic criteria for IgG4-related disease (IgG4RD), 2011. Mod Rheumatol 2012; 22: 21-30.

27. Küttner $H$ : Über entzündliche Tumoren der Submaxillar-Speicheldüse. Beitr Klin Chir 1896; 15: 815 .

28. Geyer JT, Ferry JA, Harris NL, Stone JH, Zukerberg $L R$, Lauwers GY, et al.: Chronic sclerosing sialadenitis (Küttner tumor) is an IgG4-associated disease. Am J Surg Pathol 2010; 34: 202-210.

29. Ahuja AT, Richards PS, Wong KT, King AD, Yuen $H Y$, Ching $A S$, et al.: Kuttner tumour (chronic sclerosing sialadenitis) of the submandibular gland: sonographic appearances. Ultrasound Med Biol 2003; 29: 913-919.

30. Isacsson $G$, Lundquist $P G$ : Salivary calculi as an aetiological factor in chronic sialadenitis of the submandibular gland. Clin. Otolaryngol. Allied Sci 1982; 7: 231-236.

31.Ikeda M, Ikui A, Tanaka M, Omori H, Tomita H: Immunohistopathological investigation on unspecific chronic sclerosing sialadenitis of the submandibular gland (Küttner tumor). Auris Nasus Larynx 1994; 21: 103-110.

32. Räsänen O, Jokinen K, Dammert K: Sclerosing inflammation of the submandibular salivary gland (Küttner tumour). A progressive plasmacellular ductitis. Acta Otolaryngol 1972; 74: 297-301.

33. Takano K, Yamamoto M, Takahashi H, Shinomura Y, Imai K, Himi T: Clinicopathologic similarities between Mikulicz disease and Küttner tumor. Am J Otolaryngol 2010; 31: 429-434.

34. Mikulicz J: Über eine eigenartige symmetrishe Erkrankung der Thranen und Mundspeicheldrüsen. Stuttgart: Beitr Chir Fortsch Gewidmet Theodor Billroth 1892: 610-630.

35. Schaffer AJ, Jacobsen AW: Mikulicz's syndrome: a report of ten cases. Am J Dis Child 1927; 34: 327 346.

36. Aga M, Kondo S, Yamada K, Sawada-Kitamura S, Yagi-Nakanishi S, Endo K, et al.: Warthin's tumor associated with IgG4-related disease. Auris Nasus Larynx 2013; 40: 514-517.

37. Aga M, Kondo S, Yamada K, Wakisaka N, YagiNakanishi S, Tsuji A, et al.: Immunoglobulin class switching to IgG4 in Warthin tumor and analysis of serum IgG4 levels and IgG4-positive plasma cells in the tumor. Hum Pathol 2014; 45: 793-801.

38. Inoue D, Zen $Y$, Sato $Y$, Abo $H$, Demachi $H$, 
Uchiyama $A$, et al.: IgG4-Related Perineural Disease. Int J Rheumatol 2012; 2012:401890. doi: 10.1155/2012/401890

39. Ohno K, Sato Y, Ohshima K, Takata K, Ando M, Abd Al-Kader L, et al.: IgG4-related disease involving the sclera. Mod Rheumatol 2014; 24: 195 198.

40. Takahira M, Ozawa Y, Kawano M, Zen Y, Hamaoka $S$, Yamada K, et al.: Clinical Aspects of IgG4-Related orbital inflammation in a case series of ocular adnexal lymphoproliferative disorders. Int J Rheumatol 2012;2012:635473. doi: 10.1155/2012/635473

41. Wallace ZS, Khosroshahi A, Jakobiec FA, Deshpande $V$, Hatton MP, Ritter J, et al.: IgG4related systemic disease as a cause of "idiopathic" orbital inflammation, including orbital myositis, and trigeminal nerve involvement. Surv Ophthalmol 2012; 57: 26-33.

42. Cheuk W, Chan JK: Lymphadenopathy of IgG4related disease: an underdiagnosed and overdiagnosed entity. Semin Diagn Pathol 2012; 29: 22634.

43. CheukW, Chan JK: IgG4-related sclerosing disease: a critical appraisal of an evolving clinicopathologic entity. Adv Anat Pathol 2010; 17: 303-332.

44. Li Y, Bai Y, Liu Z, Ozaki T, Taniguchi E, Mori I, et al.: Immunohistochemistry of IgG4 can help subclassify Hashimoto's autoimmune thyroiditis. Pathol Int 2009; 59: 636-641.

45. Kakudo K, Li Y, Hirokawa M, Ozaki T: Diagnosis of Hashimoto's thyroiditis and IgG4-related sclerosing disease. Pathol Int 2011; 61: 175-183.

46. Hu EK, Parrish C, Wrobel B, Deshpande V, Stone $J H$ : Immunoglobulin G4-related disease presenting as an ethmoid and maxillary mass. Ann Allergy Asthma Immunol 2013; 111: 75-77.
47. Ishida M, Hotta $M$, Kushima R, Shibayama $M$, Shimizu T, Okabe H: Multiple IgG4-related sclerosing lesions in the maxillary sinus, parotid gland and nasal septum. Pathol Int 2009; 59: 670-675.

48. Pace C, Ward $S$ : A rare case of IgG4-related sclerosing disease of the maxillary sinus associated with bone destruction. J Oral Maxillofac Surg 2010; 68: 2591-2593.

49. Schiffenbauer AI, Wahl C, Pittaluga S, Jaffe ES, Hoffman $R$, Khosroshahi A, et al.: IgG4-related disease presenting as recurrent mastoiditis. Laryngoscope 2012; 122: 681-684.

50. Gontarz M, Wyszyńska-Pawelec G, Zapała J, Gałazka K, Tomaszewska R, Lazar A: IgG4-related disease in the head and neck region: report of two cases and review of the literature. Pol J Pathol 2016; 67: 370-375.

51. Sato Y, Takeuchi M, Takata K, Ohno K, Iwaki N, Orita $Y$, et al.: Clinicopathologic analysis of IgG4related skin disease. Mod Pathol 2013; 26: 523 532.

52. Kamisawa T, Shimosegawa T, Okazaki K, Nishino T, Watanabe H, Kanno A, et al.: Standard steroid treatment for autoimmune pancreatitis. Gut 2009; 58: 1504-1507.

53. Khosroshahi A, Stone JH: Treatment approaches to IgG4-related systemic disease. Curr Opin Rheumatol 2011; 23: 67-71.

Address: 31-826 Kraków, Os. Złotej Jesieni 1

Tel./Fax.: +4812 6468836

e-mail: dmfscmuj@wp.pl

Received: 2nd March 2017

Accepted: 23rd April 2017 